\title{
METODA COMPARATIVĂ - O USTENSILĂ EPISTEMOLOGICĂ NECESARĂ ÎN STUDIILE DE DREPT COMPARAT
}

\author{
DOI:10.24193/SUBBiur.62(2017).4.9 \\ Published Online: 2017-12-20 \\ Published Print: 2017-12-30
}

\section{Alina-Emilia CIORTEA*}

\begin{abstract}
The comparative method: a necessary epistemological tool in comparative legal studies This essay will consider the aims of comparative law. It will argue that the comparative method is the needed epistemological tool for every legal theoretician who conducts comparative studies. Further on, the article will state a definition that was envisaged by scholars along with the author's proposed definition. The history of the comparative method will be examined in details, explaining how the steps of comparison work in practice. Afterwards, each element of the comparative method will be developed and it will be further considered what is to be understood by the comparability of the terms to be compared. Also, it will be valuable to look at the relationship between the comparative method and juxtaposition and, in particular, to some of the weaknesses and strengths of both of these terms. By way of conclusion, some observations will be made on how the proposed definition of the comparative method is more appropriate and more comprehensible then the ones that were already phrased by scholars.
\end{abstract}

Keywords: comparative law, comparative method, juxtaposition, terms to be compared, comparative method's definition, history of comparative method, tertium comparationis. comparative method's elements, Romanian Law, French Law, Anglo-American Law, equity.

Rezumat: Prezentul studiu este dedicat analizei metodei comparative, o ustensilă epistemologică indispensabilă oricărui cercetător care întreprinde demersuri comparative în cadrul științelor juridice. De asemenea, articolul prezintă, alături de definițiile care au fost propuse de-a lungul timpului metodei comparate și o definiție proprie a autorului cu privire la această metodă. Studiul prezintă istoricul evoluției metodei comparative, evidențiind modul în care se aplică, în practică, etapele comparării. Apoi, fiecare element al metodei comparative este detaliat și se exemplifică problema comparabilității termenilor de comparat. Totodată, sunt analizate particularitățile metodei comparative, ale juxtapunerii, precum și relația dintre acestea. Nu în ultimul rând, studiul demonstrează motivul pentru care definiția propusă de autor a metodei comparative este mai adecvată și mai inteligibilă decât cele anterior enunțate de literatura juridică.

Cuvinte-cheie: drept comparat, metodă comparativă, juxtapunere, termeni de comparat, definiția metodei comparative, evoluție istorică a metodei comparative, tertium comparationis, elementele metodei comparative, drept român, drept francez, drept anglo-american, echitate.

\section{5}




\section{Introducere}

Dreptul comparat se aseamănă foarte mult cu o excursie în care protagoniștii, comparatistul și turistul, sunt chemați să iasă din rutina cotidiană și din mediul familiar pentru a putea cunoaște și înțelege elementele care, până la acel moment, nu erau complet elucidate. ${ }^{1}$ Studiul unui drept străin, precum și efectuarea unei călătorii pe alte meleaguri deschid automat noi orizonturi? Care este pregătirea intelectuală pe care trebuie să o realizeze fiecare inițiator și care sunt ustensilele epistemologice indispensabile cercetării?

În primul rând, turistul trebuie să se ferească de capcana tentantă de a gândi locul pe care îl vizitează ca fiind asemănător sau diferit de lumea în care trăiește. Abordarea unei asemenea atitudini este dificilă, dar nu imposibilă. Pentru aceasta, se impune ca turistul să facă un efort conștient de a se detașa de imaginea familiară a propriei culturi și să acorde o atenție sporită detaliilor variate și neomogene, ferindu-se astfel de reiterarea imaginilor cunoscute ale propriei vieți, pentru a putea aprecia deplin descoperirile făcute pe durata călătoriei. Astfel, acesta ajunge să dobândească un bagaj informațional și cultural valoros, care îi lărgește orizontul și capacitatea intelectuală. ${ }^{2}$ În concluzie, dezideratul turistului de a-și lărgi orizontul cultural nu poate fi atins printr-o simplă interacțiune cu mediul străin.

În al doilea rând, dacă turistul își direcționează atenția asupra aspectelor arhitecturale, comparatistul cercetează normelor juridice. În aceste condiții, care este asemănarea între cele două situațiii Expus în mod metaforic, în ambele circumstanțe, cunoștințele anterioare și cele noi fuzionează. Condiția esențială a acestei contopiri este cunoașterea aprofundată a celor două culturi sau ordini juridice. Ulterior dobândirii informațiilor specifice propriului sistem, se impune distanțarea cercetătorului de cunoașterea dobândită (demers obiectiv ${ }^{3}$ ). Apoi, prin osmoza noțiunilor acumulate, cercetătorul va nuanța diferențe de substanță (demers subiectiv $^{4}$ ) între culturile comparate. Astfel, omul, în ambele ipostaze, de comparatist sau de turist este capabil să regândească percepțiile părtinitoare ale propriei culturi sau al propriului sistem juridic.

Din perspectivă epistemologică, poate turistul sau comparatistul neînzestrat cu nicio ustensilă să își îndeplinească misiunea? Suntem de părere că răspunsul nu poate fi decât negativ. La fel cum turistul are nevoie de hărți, ghiduri turistice și de o garderobă adecvată, la fel și comparatistului îi este utilă și indispensabilă metodă comparativă.

Ce este metoda comparativă și cum a apărut? Care sunt elementele metodei comparative? De asemenea, în ce măsură se poate susține că orice demers comparativ poate fi califica ca fiind o metodă comparativă?

În continuare, vom încerca să deslușim, fără a avea pretenția de exhaustivitate, tainele metodei comparative. Astfel, vom studia definiția metodei comparative (I), istoria acesteia (II), elementele metodei (III), urmând a verifica comparabilitate termenilor de comparat (IV) și, nu în ultimul rând, vom detalia în ce măsură noțiunea de juxtapunere se identifică cu metoda comparativă (V). 


\section{Definiția metodei comparative}

Este oare posibil ca definirea noțiunii de metodă comparativă să constituie un proces anevoios, fragmentar și aluziv? În caz afirmativ, care ar putea fi un potențial raison d'être a acestui status quo? Putem susține că, la momentul actual, nu există o definiție a metodei comparative unanim acceptată de doctrina internațională?

În primul rând, după cum vom vedea în următoarea secțiune a acestui articol, dezbaterea doctrinară tumultoasă cu privire la distincția, precum și la relația dintre drept comparat, metodă comparativă și știința dreptului comparat ${ }^{5}$ și-a pus amprenta și asupra formulării unei definiții corecte și funcționale a metodei. Astfel, în 1972 s-a constat, în mod riguros, după părerea noastră, că „studiul metodei comparative a fost întotdeauna incident și incomplet" ${ }^{\prime \prime}$, conducând la o confuzie metodologică generală datorită lipsei de precizie a cercetărilor comparatiștilor, dar și a înlănțuirii unor controverse multiple în ceea ce privește definiția metodei comparative. ${ }^{7}$

În al doilea rând, s-a susținut că este foarte dificil pentru un comparatist să formuleze observații metodologice fără a fi el însuși implicat în procesul de cercetare. ${ }^{8}$ Astfel, afirmațiile unui comparatist capătă valoare științifică numai în măsura în care studiul terminologiei juridice și al dreptului ca ansamblu juridic s-a realizat prin simțurile proprii ale comparatistului. Cercetarea nemijlocită poate avea loc doar prin cunoașterea și prin familiarizarea cercetătorului cu fundamentele sistemului juridic cercetat, cu istoria, cu sociologia, cu literatura etc. specifică ordinii juridice respective. ${ }^{9}$ Or, întrunirea cumulativă, în persoana comparatistului, a acestor criterii constituie un fenomen rar întâlnit, fapt ce conduce adesea la imposibilitatea acestuia din urmă de a formula opinii doctrinare relevante și consistente.

În al treilea rând, surmontând piedicile apărute de-a lungul parcursului evolutiv, suntem de părere că, actualmente, metoda comparativă poate fi determinată în termeni științifici. Astfel, metoda comparativă este definită ca fiind „ansamblul demersurilor și al procedeelor, care se înlănțuie potrivit unei proceduri raționale, menite să facă spiritul juridic să constate și să înțeleagă, printr-un proces ordonat, metodic și progresiv, de confruntare și de comparare, asemănările, diferențele și cauzele acestora, adică în cele din urmă să desprindă raporturile existente între structurile și funcțiile termenilor de comparat ce aparțin unei ordini juridice diferite."10

În considerarea acestei definiții, se ridică, în mod legitim, următoarele întrebări: când și cum a apărut metoda comparativă? Care sunt elementele metodei comparative? Este necesar ca termenii de comparat ${ }^{11}$ să fie compatibili per se, ori compatibilitatea este creionată de comparatist? Poate fi găsită o utilitate practică a concluziilor extrase în urma comparării a doi termeni care, deși aparent comparabili, nu prezintă niciun element comun din perspectivă juridică? Există anumite faze ale procesului metodologic? Care sunt acestea? Și nu în ultimul rând, se poate pune semnul echivalenței între metoda comparativă și juxtapunerea termenilor de comparat?

\section{7}




\section{Scurt istoric al metodei comparative}

Pe continentul european, problema metodologiei s-a pus pentru prima dată în dreptul german, în a doua jumătate a secolului al XIX-lea. ${ }^{12}$ În Franța, Edouard Lambert a fost primul care a lansat o dezbatere asupra acestor chestiuni în cadrul Congresului Internațional de Drept Comparat, organizat la Paris, în anul $1900 .^{13}$

Teoretizarea unui instrument științific precum metoda comparativă a necesitat multă rigoare și dedicare. Astfel, evoluția doctrinei, în ceea ce privește metoda comparativă, a parcurs mai multe etape.

La începuturi, în Franța, demersul comparativ a fost unul pur empiric ${ }^{14}$, nefiind cunoscută clasificarea comparației în micro și macro-comparație. ${ }^{15}$ Care a fost obiectul de studiu, din această perioadă, al metodei comparative? Autorii s-au concentrat, în principal, pe studiul legislației și al codurilor din diverse jurisdicții. Așadar, obiectivul principal a fost cunoașterea progresului din alte țări în ceea ce privește domeniul juridic. Și totuși, această abordare a fost virulent criticată. În principal, i s-a reproșat lipsa cursivității metodologice, datorită faptului că a fost realizată superficial și fără referiri contextuale. ${ }^{16}$

Abordarea pur empirică a metodei comparative a primit, retroactiv, denumirea de metodă descriptivă. ${ }^{17}$ Analizând modul de abordare al metodei descriptive, Constantinesco subliniază că, juristul educat în sistemul de drept romano-germanic are tendință eronată de a considera că întreg sistemul juridic se rezumă la legi și la coduri. ${ }^{18} \mathrm{O}$ atare interpretare este nesusținută, deoarece legea nu reprezintă întreg dreptul. ${ }^{19}$ Comparatistul trebuie să utilizeze doctrina, jurisprudența, practica în afacerii și cutuma, alături de legile și de codurile din ordinile juridice analizate. ${ }^{20} \mathrm{Cu}$ toate că unele dintre ustensilele de care se folosește comparatistul nu constituie izvoare de drept în sistemul juridic supus cercetării științifice, formarea unui viziuni de ansamblu asupra ordinii juridice este vitală, întrucât fiecare dintre aceste elemente contribuie la evoluția dreptului și la justificarea istoriei acestuia.

Începând cu debutul secolului al XX-lea, metoda comparativă a devenit un subiect de studiu și de analiză. Diverși autori (Kholer, Lambert, Schwarz-Liebermann Von Wahlendorf etc. $)^{21}$, prin opiniile exprimate și prin studiile realizate, au schițat conturul metodei comparative, fără a se putea mândri cu obținerea unei sistematizări, respectiv a unei coerențe de ansamblu asupra problemei. ${ }^{22}$

În continuarea demersului intelectual lansat la sfârșitul secolului al XIX-lea, un curent doctrinar, al cărui promotor a fost Leontin-Jean Constantinesco, tinde să se detașeze de caracterul empiric al metodei comparative. ${ }^{23}$ Astfel, autorul susține că metoda comparativă „constă în a conduce un studiu comparativ de-a lungul a trei stadii succesive, și anume: connnaître, comprendre, comparer". ${ }^{24}$ Prin acest demers se urmărește oferirea unui cadrul metodologic propice comparatistului pentru a putea opera cu finețe subtilitățile elementelor de comparat din ordinea juridică cercetată, în vederea atingerii unui scop precis. Cele trei faze ale procesului metodologic sunt cunoscute și sub numele de regula celor trei $C{ }^{25}$

Prima faza, intitulată connnaître (a cunoaște), înglobează toate acțiunile necesare pentru cunoașterea termenilor de comparat ${ }^{26}$ (analizarea termenului de comparat așa cum este, respectiv studierea termenului de comparat în cadrul izvoarelor sale din ordinea juridică 
respectivă ${ }^{27}$ și în complexitatea acestora, respectarea ierarhiei izvoarelor de drept și, nu în ultimul rând, întrebuințarea metodei de interpretare specifică ordinii juridice de care aparține termenul de comparat). ${ }^{28}$

Dacă în prima fază, comparatistul s-a familiarizat cu termenii de comparat, izolat de ordinea sa juridică, în următoarea etapă cunoscută sub numele de comprendre (a înțelege), cercetătorul va utiliza toate operațiunile metodologice necesare înțelegerii termenilor de comparat în cadrul peisajului juridic din care provin. Astfel, pentru început, comparatistul a întreprins o operațiune de zoom in și de focalizare asupra fiecărei particule a termenului de comparat, privit in individualitatea lui, precum turistul fotografiază curios detaliile arhitecturale ale unor clădiri istorice. Comparatistului, dar și turistului nu le este suficientă o viziune de detaliu. Așadar, este absolut necesară integrarea termenul de comparat în ordinea juridică respectivă și analizarea lui în relație cu toate influențele juridice și extra-juridice (sociologice, istorice, economice și lingvistice) care se exercită asupra termenului. ${ }^{29}$ Turistul va proceda identic, întrucât după o fotografie de detaliu, se va orienta spre captarea unei imagini de ansamblu. Operațiunea aceasta de zoom out este vitală pentru o înțelegere rațională a utilității globale a elementului arhitectural, vizualizat anterior în detaliu. ${ }^{30}$

A treia fază, denumită comparer (a compara), cuprinde acțiunile menite să îl ajute pe comparatist să relaționeze termenii de comparat, pentru a putea stabili raporturile de asemănare sau de deosebire existente între aceștia. ${ }^{31}$ Pentru a compara este absolut necesar a înțelege, iar pentru a înțelege este nevoie de cunoaștere. ${ }^{32}$

În fond, primele două faze sunt menite să furnizeze informațiile necesare comparării finale, realizată în ultima etapă, aceea a comparării efective. În cadrul acestei faze, comparatistul urmărește observarea raportului existent între fiecare element al termenului de comparat, mergând de la particular la general, de la analiză la sinteză. ${ }^{33}$ Demersul apreciativ și critic poartă o puternică amprentă subiectivă, întrucât activitatea de compararea presupune interpretare, comparație și alegeri. ${ }^{34}$ Prezentarea asemănărilor și/sau a deosebirilor între termenii de comparat nu urmărește măsurarea raporturilor de paralelism instituțional sau, din contră, de diversitate, ci dimpotrivă evidențierea scopului urmărit de comparatist. ${ }^{35}$ Astfel, dreptul comparativ trimite la o teorie a argumentării, care este de fapt o interferență a descoperirii și a justificării. ${ }^{36}$ Turistul trăiește o experiență asemănătoare. Prin prisma rezistenței la prejudiciile propriei culturi, reușește să obțină atât o viziune de detaliu, cât și una generică, de ansamblu cu privire la elementele noii culturi pe care o explorează. Apoi, cu acest bagaj informațional, turistul va putea prezenta o viziune documentată cu privire la identitatea sau diversitatea dintre locul său natal și cel al țării pe care o vizitează. în măsura în care turistul avansează direct la comparare, sărind peste primele două faze, acesta redescoperă doar peisaje din trecutul său, întrucât călătorind legat la ochi, nu poate să aprecieze pe deplin frumusețea și unicitatea locului pe care îl vizitează. ${ }^{37}$

Schematic, cele trei faze metodologice pot fi imaginate ca trei tronsoane orizontale ale unei piramide secționate. Acestea nu sunt ermetic separate, ci prin complementaritatea și solidaritatea lor ajută la demersul cercetării întreprins de către comparatist. ${ }^{38}$

În concluzie, începând cu secolul aI XIX-lea, eforturile doctrinare au adus îmbunătățiri substanțiale metodei comparative. Dacă în fazele incipiente ale metodei comparative, 
noțiunea și elementele de bază nu au fost metodologic delimitate, evoluția ulterioară a adus un plus de rigoare, claritate și consistență. Acum, putem oare afirma că metoda comparativă a ajuns la capătul stagiului evolutiv sau acesta este doar începutul unei teoretizări consistente? Pentru a oferi un răspuns pertinent, se impune analiza detaliată a atomilor metodei comparative și a rolului acestora în metodologia dreptului comparat.

\section{Elementele metodei comparative}

Cele patru elemente esențiale, deduse din definiția metodei comparative ${ }^{39}$ sunt: realizarea unui comparații sistemice, existența unui scop precis, utilizarea a cel puțin doi termeni de comparat și apartenența termenilor de comparat la două ordini juridice diferite. ${ }^{40}$

Pentru ca un demers științific să poată fi caracterizat ca având caracterele unei metode comparative este absolut necesar a exclude orice abordări haotice, executate la întâmplare, fragmentate sau contradictorii. Astfel, compararea trebuie să fie sistematică, logică și coerentă.

Dacă în alte domenii s-ar putea accepta efectuarea unor studii al căror scop să fie deslușit pe parcurs, în ceea ce privește metoda comparativă, existența unui scop precis nu poate fi supusă unui compromis. Incizia în ordinele juridice supuse operațiunii de comparație este efectuată de comparatist care, folosind metoda comparativă, urmărește elucidarea asemănărilor și deosebirilor existente între termenii de comparat.

Metoda comparativă impune utilizarea a cel puțin doi termeni de comparat. Termenul de comparat este noțiunea care „înglobează particulele juridice elementare" ${ }^{\prime 1}$ din cadrul unor ordine juridice diferite, adică „,regulile, instituțiile juridice, funcțiile sau problemele juridice care sunt de comparat." 42

Nu în ultimul rând, este indispensabilă, pentru metoda comparativă, existența a cel puțin două ordini juridice diferite în care să se regăsească termenii de comparat pentru a putea proceda la comparare eficientă. ${ }^{43} \mathrm{Nu}$ este exclusă utilizarea mai multor ordini juridice, însă aceasta alegere o va face comparatistul în funcție de pregătirea sa și de scopurile urmărite. Deși, inițial, comparatiștii au avut tendința de a îngloba cât mai multe ordini juridice în studiile lor, acum, din dorința de a conferi un plus de profunzime cercetării (în pofida vizibilei pierderi cantitative), ordinele juridice comparate sunt în număr mai redus. ${ }^{44}$

Poate fi considerat tertium comparationis un al cincilea element al metodei comparative ${ }^{45}$ Literatura de specialitate a susținut, în mod întemeiat, ineficiența utilizării noțiunii de tertium comparationis, întrucât compararea se face întotdeauna utilizând ordini juridice concrete. Raportarea la o unitate de măsură exterioară și prestabilită nu poate fi efectuată, deoarece aceasta nu există și nici nu ar putea exista în cadrul dreptului. ${ }^{46}$

În măsura în care sunt întrunite toate elementele metodei comparative, un profan ar fi tentat să pledeze în favoarea libertății neîngrădite a comparatistul de a jongla cu orice termeni, indiferent de ordinea juridică de care aceștia aparțin. Însă, lucrurile sunt departe de a fi atât de tranșante. Compararea termenilor de comparat depinde de comparabilitatea acestora, caracteristică ce se află întipărită în ADN-ul acestora. Și totuși, ce se înțelege prin comparabilitate? 


\section{Comparabilitatea termenilor de comparat}

În doctrină, problema comparabilității se analizează, pe două paliere: la nivelul termenilor de comparat și în planul ordinilor juridice diferite supuse comparării. ${ }^{47}$ Preponderent, ne vom axa exemplificarea problemei comparabilității asupra primului palier, respectiv cel al termenilor de comparat, atingând doar tangențial cel de-al doilea nivel, reprezentat de comparabilitatea ordinilor juridice cărora aparțin textele de comparat.

Ce calități sau trăsături trebuie să aibă termenii pentru ca aceștia să poate fi comparați? Este nevoie de existența unui element comun între termenii de comparat? Se rezumă oare comparabilitatea la paralelismul lingvistic al termenilor de comparat?

În vederea întreprinderii acestui demers științific, vom porni raționamentul de la un exemplu concret. Care ar fi rezultatul dacă un comparatist și-ar alege, pentru început, trei sisteme de drept: unul aparținând sistemului anglo-saxon (Anglia), iar al doilea și al treilea de inspirație romano-germanică (Franța, respectiv România) selectând drept termen de comparat noțiunea de equity (engleză) ${ }^{48}$, de équité (franceză) ${ }^{49}$, respectiv de echitate? S-ar putea afirma cu certitudine că rezultatul care s-ar obține în urma comparării ar fi unul cu valoare științifică?

În primul rând, pentru a putea cunoaște termenul de comparat (parcurgând prima faza a procesului metodologic, intitulată connaître) trebuie operată o analiză detaliată a acestuia. Apoi, după ce comparatistul a deprins cunoștințele necesare în ceea ce privește termenul de comparat, se impune reintegrarea acestuia în peisajul juridic de care aparține, pentru înțelegerea complexă a fiecărui element specific termenului de comparat, operațiuni care se desfășoară în faza denumită comprendre. Întrucât cele două faze ale procesului metodologic nu sunt ermetic separate, dar și pentru o mai bună fluență a prezentului discurs, le vom analiza împreună.

Care este semnificația noțiunii de equity în dreptul anglo-saxon? Fără a intra în prea multe detalii cu privire la sistemul juridic englez, acțiune care ar exceda scopul prezentului articol, menționăm că, la sfârșitul secolului al XIII-lea, trei instanțe judecătorești erau deja ferm constituite în Anglia și aplicau așa-numitul drept Common Law, adică dreptul comun întregii țări..$^{50}$ În fața acestor instanțe reclamantul, pentru a-și putea susține cauza, avea nevoie de un writ ${ }^{51}$, adică de un ordin prestabilit care corespundea doar situațiilor factuale care se iveau cel mai des în practica judiciară a acelor vremuri. ${ }^{52}$

Spre exemplu, normele juridice aplicabile în Common Law ofereau un remediu persoanelor al căror consimțământ, la încheierea unui contract, a fost viciat prin amenințări la adresa vieții sau care vizau integritatea corporală sau sănătatea. ${ }^{53}$ Însă, aceste norme nu ofereau victimelor violenței morale nicio acțiune eficientă. În consecință, plasându-ne în secolul al XIV-lea, ne punem întrebarea: exista vreun remediul juridic oferit de normele de Common Law, de pildă, unei femei căsătorite care, aflându-se într-o situație financiară precară, a încheiat un contract vădit dezavantajos cu soțul său care a profitat de această circumstanță, stipulând în favoarea lui ? ${ }^{54}$ Răspunsul, deși inechitabil ${ }^{55}$ și injust, nu poate fi decât negativ. Așadar, datorită faptului că societatea a evoluat, writ-urile existente nu mai corespundeau nevoilor oamenilor. Implementarea unei schimbări se impunea de urgență. 
Ca reacție la îngrădirea injustă a accesului la justiție, ${ }^{56}$ în secolul al XV-lea p. Chr., a fost introdus sistemul de Equity. Acesta reprezintă setul de reguli juridice de drept elaborate de către Cancelar, un ofițer al regelui, pentru a înlătura rigorile dreptului aplicabil în Common Law. ${ }^{57}$ Cancelarul oferea victimei care nu era apărată în sistemul de Common Law, un writ prin care ordona pârâtului să se înfățișeze înaintea lui și să răspundă sub jurământ la acuzațiile ce i se aduc. ${ }^{58}$ Astfel, deși Equity a apărut ca un set de reguli aplicabile în cazuri izolate și conform regulilor moralei din acea perioadă, ulterior s-a dezvoltat într-un veritabil set de norme juridice.

O perioadă cele două instanțe au funcționat în paralel. În anul 1875, prin Judicature Acts, s-a înființat Curtea Supremă de Justiție care, din acel moment, urma să aplice atât normele de Common Law, cât și cele specifice instanțelor ecleziastice care utilizau principiile de Equity. ${ }^{59}$ Această fuziune a avut ca scop unificarea și simplificarea regulilor procedurale, întrucât, în planul dreptului substanțial, în situația în care se ivea un conflict între normele de Common Law și cele de Equity, acestea din urmă prevalau. ${ }^{60}$

Care este optica franceză în ceea ce privește noțiunea de équité? Cum se reflectă echitatea în dreptul român? Putem afirmă că există, pe lângă paralelismul lingvistic, și un plan al echivalenței juridice între équité, Equity și echitate?

Pentru început, ar fi impardonabilă omisiunea de a sublinia faptul că diviziunea fundamentală Common Law - Equity este ignorată în Europa continentală. În dreptul de inspirație anglo-saxonă, diviziunea fundamentală dintre Common Law și Equity nu se bazează pe niciun fundament logic, ci se datorează evoluției istorice a dreptului englez. ${ }^{61}$ Așadar, în Franța noțiunea de équité nu are semnificația pe care am identificat-o anterior în sistemul juridic englez, întrucât istoria celor două țări se întemeiază pe piloni diferiți. în esență, dreptul de inspirație romano-germanică este centrat pe lege, ${ }^{62}$ care cuprinde norme generale și principii abstracte. ${ }^{63}$ Judecătorul, deși dispune de o marjă largă de interpretare, nu îi este recunoscută posibilitatea de a crea norme juridice cu caracter general și forță obligatorie. ${ }^{64}$ De cealaltă parte, dreptul englez are un pronunțat caracter cazuistic, întrucât practicienii și judecătorii creează dreptul în funcție de fiecare stare de fapt cu care aceștia lucrează, exprimându-și reticență față de o sistematizare și o teorie generală a normelor de drept.

La o analiză în detaliu a dreptului francez, observăm că noțiunea de équité nu îi este total străină. Prezența termenului poate fi remarcată încă din anul 1800, în cuprinsul articolului 11 din Proiectul Codului Civil. ${ }^{65}$ Conținutul articolului 11 nu a fost incorporat în Codul Civil francez de la 1804, deoarece s-a considerat că, prin cuprinsul său, acest articol ar da un accent filosofic excesiv normelor juridice și ar conferi hotărârilor judecătorești calitatea de izvor direct de drept. ${ }^{66}$ Astfel, s-a susținut că, prin introducerea articolului 11 din Proiect în Codul Civil francez, s-ar ajunge la o suprapunere a noțiunii de équité cu cea de Equity din sistemul anglo-saxon, fapt ce ar submina autoritatea și importanța normelor cuprinse în Codul Civil, ${ }^{67}$ apropiind cele două sisteme, sub acest aspect, până la identitate. Într-un context diferit, redactorii Codul Civil francez au uzat de termenul équité. În aceste circumstanțe, ce se înțelege prin echitate, în dreptul francez? 
Eficiența pragmatismului ne îndeamnă să demarăm exemplificarea pornind de la o normă de drept concretă. De pildă, art. 1194 din Codul civil francez situat în secțiunea dedicată efectelor contractului, respectiv subsecțiunea intitulată forța obligatorie utilizează, în cuprinsul său, noțiune de équité. ${ }^{68}$ Perspectiva din care acest articol abordează noțiunea de echitate o reprezintă rolul interpretativ al judecătorului. ${ }^{69}$ Dacă în sistemul de Common Law, judecătorul creează reguli de drept, în dreptul romano-germanic menirea acestuia este de a aplica și interpreta legea ${ }^{70}$ la starea de fapt cu care este investit. În acest context, ce reprezintă echitatea, ca sursă interpretativă exterioară contractului și dreptului pozitiv? Întrucât o explicație mai evocatoare este dificil de exprimat, ne vom referi la ideile expuse de Portalis, la începutul secolului al XIX-lea. ${ }^{71}$ Acesta susținea că echitatea se definește ca o întoarcere la dreptul natural, acolo unde legea este evazivă, obscură sau insuficientă. ${ }^{72}$ Așadar, echitatea este adevăratul supliment al legislației pe care judecătorul, în considerarea poziției sale, o aplică la fiecare caz particular cu care se confruntă, completând caracterul general și abstract al legilor din sistemul de drept romano-germanic. ${ }^{73}$

Dacă din legislația franceză am ales un exemplu de text normativ care face trimitere directă la équité, ne întrebăm în ce măsură, în contextul dreptului român, se poate vorbi despre echitate chiar dacă o normă juridică nu face trimitere expresă la această noțiune? ${ }^{74}$ Pentru exemplificare, vom alege instituția reprezentării succesorale, reglementată la art. 965-969 noul Cod civil.

Reprezentare succesorală este un beneficiu legal acordat exclusiv descendenților copiilor defunctului și descendenților fraților sau surorilor defunctului, care permite acestora să împrumute gradul și dreptul succesoral al antecesorului ${ }^{75}$ pentru a veni la moștenirea lui de cuius la care nu ar fi avut vocație succesorală în lipsa reprezentării. ${ }^{76}$

În prima reglementare scrisă a reprezentării succesorale, respectiv în Instituțiile lui lustinian, regăsim consacrarea expresă a cuvântului echitate, considerându-se că acesta este adevăratul motiv pentru care se impune implementarea instituției. ${ }^{77}$ Astfel, reprezentarea succesorală corectează aplicarea mecanică și uneori nedreaptă a principiului proximității gradului de rudenie între membrii aceleași categorii de succesori.

Este echitabil ca, atunci când un moștenitor încetează din viață înaintea lui de cuius, descendenții acelui moștenitor să poată veni la succesiunea defunctului, având posibilitatea de a dobândi cota succesorală cuvenită antecesorului lor. Așadar, reprezentare previne nedreptatea ce ar putea fi creată în cazul unei cronologii anormale a deceselor în familie. ${ }^{78}$

Spre deosebire de Codul civil de la 1864, conform căruia puteau fi reprezentate doar persoanele predecedate, reglementarea din 2011 a reacționat la criticile doctrinare ${ }^{79}$ și a permis, alături de reprezentarea predecedatului și reprezentarea nedemnului. Astfel, în măsura în care un moștenitor al defunctului este nedemn față de acesta din urmă, este inechitabil și ilogic ca sancțiunea strict personală care îi este aplicată numai nedemnului, să îi înlăture de la moștenire pe descendentul acestuia care, în lipsa pedepsei civile, ar fi venit la moștenirea lui de cuius.

De-a lungul timpului, legiuitorul a operat diferite modificări la nivelul reglementării instituției reprezentării succesorale. Astfel, începând cu secolul al XIX-lea, noțiunea de echitate nu a mai fost reiterată în cuprinsul definiției legale a reprezentării succesorale. Cu toate acestea,

\section{3}


putem susține, fără ezitare, că fundamentul reprezentării se regăsește tot în echitate, întrucât aceasta își găsește corespondentul într-o realitate socială perpetuă.

Prin urmare, observăm că și în cazul unei norme juridice care nu face trimitere expresă la echitate, aceasta se regăsește în însăși rațiunea reglementării, justificându-i necesitatea, conținutul și aplicabilitatea.

În al doilea rând, după ce comparatistul a cunoscut și a înțeles termenii de comparat din fiecare ordine juridică, urmează procesul efectiv de comparare (fază intitulată comparer) prin care cercetătorul trasează raporturile de asemănare și de deosebire dintre termenii de comparat studiați în fazele anterioare ale procesului metodologic.

În considerarea informațiilor dobândite în primele două faze, în ce măsură putem afirma că există elemente comune între noțiunile de equity, din limba engleză, varianta franceză, denumită équité și echitatea din dreptul român? Este suficientă existența unui paralelism lingvistic pentru a afirma că noțiunile analizate constituie termeni de comparat?

Este cert faptul că, noțiunile de echitate din cele trei sisteme de drept care aparțin unor familii juridice și lingvistice diferite nu prezintă, de regulă, elemente de drept comune. ${ }^{80}$

Totuși, nu poate fi contestat că, la baza noțiunilor de echitate din sistemele de drept analizate, se află principiile de drept natural. ${ }^{81}$ De pildă, François Gény a susținut că sintagma prezentă în articolul 565 din Codul Civil francez (referitor la dreptul mobiliar de accesiune) ${ }^{82}$ este similară, dintr-o anumită perspectivă, cu varianta engleză a noțiunii de echitate. ${ }^{83}$ Autorul a afirmat că, dacă este analizată cauza și scopul pentru care au fost create instanțele care aplică normele de Equity, se poate observa apropierea structurii engleze de conceptul „echității generale" din dreptul romano-germanic. ${ }^{84}$

Astfel, chiar dacă punctul de pornire coincide, traseul urmat în sistemele angloamericane și cele de drept romano-germanic diferă fundamental. În sistemul anglo-saxon, prin Equity se înțelege un întreg set de norme juridice care oferă un remediu eficient situațiilor nereglementate de Common Law. Așadar, se creează un întreg sistem de drept paralel și prevalent față de normele de Common Law. În concepția romano-germanică, ${ }^{85}$ termenul de echitate, respectiv de équité desemnează utilizarea dreptului natural drept criteriul de referință în interpretarea și aplicarea normelor de drept și a actelor juridice, precum și în justificarea existenței unor instituții de drept.

În concluzie, dacă în sistemul anglo-american, echitatea și-a câștigat independența ca normă juridică autonomă, în sistemele de inspirație romano-germanică echitatea este utilizată de juriști ca resort în cazul aprecierii conduitei părților în exercitarea drepturilor și a obligațiilor reglementate de o normă de drept, precum și în legitimarea consacrării legislative a unor instituții juridice.

Chiar dacă poate fi identificată o origine comună și o identitate lingvistică între cele trei noțiuni, regula metodologică aplicabilă în dreptul comparat conclude asupra posibilității comparării doar acolo unde există elemente comune pe plan juridic între termenii de comparat. ${ }^{86} \mathrm{Or}$, datorită evoluției distincte a noțiunii de echitate din sistemul de inspirație anglo-saxon, precum și din cele de inspirație romano-germanică, concluzionăm că acestea nu prezintă elemente juridice comune care să justifice pertinența unui studiu comparativ 
actual. Paralelismul fundamentului termenilor de comparat nu există decât la un grad mare de generalizare și abstractizare, fapt ce conduce la concluzia incomparabilității termenilor de comparat.

Observăm, așadar, că deși termenii de comparat nu sunt comparabili (fapt ce pune la îndoială însăși caracterizarea acestora ca „termeni de comparat”), anumite asemănări pot fi deduse prin folosirea mijloacelor procedurale specifice metodei comparative. ${ }^{87} \mathrm{Cu}$ toate acestea, compararea noțiunii echității, cu varianta franceză équité și cu Equity-ul englez, ca izvor de drept, conduce la rezultate absurde și de utilitate practică redusă.

În concluzie, compararea este îndreptățită doar atunci când, între particulele juridice elementare ale fiecărei ordini juridice, triate maiestos de către comparatist, existe puncte comune $^{88}$ care creează un paralelism juridic între termenii de comparat, independent sau complementar de echivalența lingvistică.

Un cititor circumspect s-a întreba care este utilitatea comparării dacă, în urma parcurgerii procesului metodologic, comparatistul ajunge la concluzia că termenii de comparat sunt, în realitatea, incomparabili? ${ }^{89}$

Pornind de la exemplu nostru, am văzut că versiunea română și franceză a echității, pe de-o parte, ${ }^{90}$ și cea engleză pe de altă parte, deși au fundamentul în aceleași principii, evoluția lor le atribuie un caracter juridic esențial diferit. Așadar, în urma constatărilor făcute în cea de-a treia fază metodologică (comparer), putem afirma că cele noțiunile nu constituie, din perspectiva dreptului comparat, termeni de comparat. Simpla prezența a principiului etic la geneza noțiunii de echitate din sisteme de drept analizate nu conferă calitatea de termeni de comparat din perspectivă juridică. ${ }^{91}$ Pentru a ajunge la această concluzie, am parcurs cele două faze premergătoare comparării, respectiv faza de cunoaștere și cea de înțelegere. Or, cum nimeni nu se poate angaja într-o comparare fără a înțelegere ceea ce $a$ priori a făcut obiectul unui proces de cunoaștere, neîncrederea în utilitatea demarării unui proces comparativ care se sfârșește prin concluzia incomparabilității noțiunilor nu poate fi temeinic susținută.

Comparatistul, utilizând metoda comparativă ca ustensilă epistemologică, pătrunde adânc în complexul fenomenului juridic studiat pentru a-l cunoaște atât din perspectivă juridică, cât și dintr-o viziune metajuridică, politică, socială, istorică etc. Cunoștințele acumulare, chiar dacă nu conduc la concluzia comparabilității termenilor, oferă comparatistului un bagaj informațional prețios. Fie că este vorba despre contribuția la crearea unor norme supranaționale, a unei legislații comune europene, a unui glosar plurilingv sau despre o mai bună cunoaștere a propriei ordini juridice a comparatistului sau a unei ordini juridice străine, polza nu poate fi contestată. Nu trebuie pierdut din vedere faptul că, metoda comparativă nu diferă în funcție de rezultatele la care comparatistul ajunge, iar utilizarea acestora în cadrul altor demersuri științifice nu influențează unitatea metodei. ${ }^{92}$

Argumentele aduse în sprijinul tezei utilității efectuării unui demers comparativ, chiar dacă acesta ar putea duce la concluzia incomparabilității elementelor, nu trebuie înțelese în sensul în care susținem întreprinderea unui proces comparativ cu privire la orice noțiuni. Din contră. Este zadarnic a sublinia că elemente precum drepturile succesorale ale

\section{5}


soțului supraviețuitor din sistemul francez și dreptul unității administrativ-teritoriale de a culege o moștenire vacantă din legislația română nu prezintă niciun element comun sau vreo echivalență. Comparabilitatea ce ar putea rezulta din faptul că ambele situații se referă la domeniul succesiunilor este doar aparentă, deoarece, ab initio, este exclusă existența comparabilității sau a unui paralelismul juridic între cei doi termeni de comparat. Însă, nu același lucru se poate afirma despre noțiuni echivalente lingvistic care, cel puțin aparent, ar putea să conducă la concluzia prezenței unor elemente comune ce leagă termenii de comparat. $^{93}$

Concluzionând, deși comparabilitatea precedă compararea, constatarea unei identități sau a unei echivalențe, structurale sau funcționale pe plan juridic a termenilor de comparat nu se poate efectua, de cele mai multe ori, decât după parcurgerea sistematică și completă a primelor două faze ale procesului metodologic, respectiv faza de cunoaștere și de înțelegere. Urmează ca, în cea de-a treia fază, cea a comparării, cercetătorul să dobândească convingerea asupra apropierii sau asupra diferențierii termenilor de comparat în funcție de gradul de comparabilitate identificat. Întrucât metoda comparativă nu este o ustensilă științifică ce poate fi folosită fără o cunoaștere sistemică și detaliată a metodologiei dreptului comparativ, atât pentru constatarea compatibilității, cât a incompatibilității, este necesară cunoașterea aprofundată a regulilor metodologice, fapt ce justifică încă o dată utilitatea practică a observațiilor trasate în prezentul articol.

\section{Juxtapunerea - o metodă comparativă camuflată?}

Între întreruperea parcursului firesc al fazelor procesului metodologic, în special al fazei comparării, prin constatarea incompatibilității termenilor de comparat și juxtapunere există o relație de sinonimie? Ce este juxtapunerea și în ce măsură poate aceasta epuiza actul comparării juridice? Putem afirma că orice juxtapunere aparține dreptului comparat, ca știință independentă?

În deschidere, studiile de drept comparat invită publicul cititor să descopere instituțiile juridice de drept străin ce alcătuiesc termenii de comparat (faza intitulată connaître). Pentru această operațiune, comparatistul ${ }^{94}$ constată particularitățile termenilor de comparat și le expune în studiul său. ${ }^{95}$ În această privință, activitatea comparatistului poate fi asemănată cu cea a unui miner. Astfel, $a b$ initio, minerul trebuie să identifice diferite zone geografice bogate în minerale, ca mai apoi să extragă din fiecare zăcământ minereul pur, urmând a-I pregăti pentru o cercetare amănunțită.

Acest demers este în mod necesar anterior, dar și indispensabil pentru prelucrarea minereului în vederea utilizării lui în procesul tehnologic. Înainte de înțelegerea deplină a calităților produsului extras, prin studierea atentă a proprietăților sale în vederea obținerii unui produs finit, util în diverse sectoare economice, este nevoie de descoperirea minereului și de cunoașterea particulelor componente. În mod similar, cercetătorul demarează comparația prin angajarea sa în studii paralele de drept străin pentru a cunoaște cu adevărat felul în 
care termenii de comparat sunt concepuți, interpretați și aplicați în fiecare din aceste ordini de drept. Oprindu-se în această etapă a procesului comparativ, rezultatul se concretizează într-un studiu de drept străin care nu se confundă cu un studiu de drept comparat. ${ }^{96}$

În primul rând, comparatistul alege termenii de comparat din diferite ordini juridice, pentru a-i pune față în față și a-i studia. Studiul se limitează la dezvăluirea raporturilor de natură tehnică între termenii de comparat. Ceea ce comparatistul efectuează constituie, de fapt, juxtapunerea particulelor juridice care fac parte din dreptul pozitiv al sistemelor de drept studiat. Așadar, cititorului îi este expusă partea vizibilă a circuitului juridic.

Revenind la exemplu nostru, care ar fi rezultatul obținut strict în urma juxtapunerii valențelor cuvântului echitate prezente în sistemelor de drept român, francez și englez? Concluzia noastră s-a rezuma, în fond, la ideea că, dacă în sistemele romano-germanice, există texte legale care fac trimitere atât expresă, cât și implicită la noțiunea de echitate, în familia dreptului anglo-saxon, echitatea desemnează, în principiu, un set de norme juridice dezvoltate, din perspectivă istorică, în paralel cu dreptul de Common Law.

Așadar, la acest nivel, cercetătorul furnizează numai materia primă brută pentru comparare. Minerul identifică zăcământul bogat în minerale și îl extrage pentru ca ulterior acesta să poată fi folosit în procesul complex de producție, la fel și comparatistul apelează la texte din diferite legislații, expunându-le conținutul, pentru ca mai apoi termenii de comparat să fie integrați în contextul socio-cultural și istoric al ordinii juridice studiate. Numai în urma dezvăluirii interacțiunilor ascunse între termenii de comparat și datele extra-juridice se poate afirma că produsul obținut este rezultatul unui studiu comparativ.

Juxtapunerii i s-ar putea imputa lipsa de utilitate practică. De ce s-ar mulțumi un cercetător cu efectuarea unui studiu de drept străin, deci cu prezentarea unor elemente de fapt, când ar putea să opteze pentru un studiu amplu, comparativ?

Un exemplu edificator îl regăsim în mecanismul aplicării unei legi străine de către instanța de judecată română chemată să soluționeze un litigiu cu elemente de extraneitate. Conform art. 253 Cod procedură civilă și a art. 2562 noul Cod civil, dovada conținutului legii străine este făcut fie de instanță din oficiu, fie de partea care o invocă. Observăm că, potrivit dispozițiilor art. 2563 noul Cod civil, odată ce proba legii străine s-a făcut, interpretarea și aplicare acesteia se realizează după regulile de interpretare și aplicare existente în sistemul de drept căruia îi aparține. Asemănător primelor două faze ale procesului metodologic specific metodei comparative, respectiv faza connaître și comprendre, instanța de judecată întreprinde un demers de cunoaștere și de familiarizare cu un alt sistem de drept, detașându-se de cunoștințele dobândite din propriul sistem de drept. Urmează ca, la soluționarea cauzei, instanța să aplice normele de drept străin. Însă, în mod excepțional, în situația în care legea cu elemente de extraneitate încalcă ordinea publică de drept internațional privat român, instanța va aplica, potrivit art. 2564 noul Cod civil, legea română. Așadar, în acest din urmă caz, instanța juxtapune principiile generale de ordine publică din dreptul român cu dispozițiile legii străine, iar în caz de conflict, dispune înlăturarea acestora din urmă. Este dincolo de orice îndoială că, în aplicarea art. 2564 noul Cod civil, instanța procedează la comparare a două ordini juridice. Totuși, operațiunea nu poate fi calificată ca reprezentând un studiu de

\section{7}


drept comparat, deoarece demersul instanței nu vizează și aspecte extra-juridice, contextul istoric, sociologic etc. al ordinii juridice străine. Mai mult, concluzia instanței se rezumă la o stare de fapt centrată în jurul normelor de drept străine, nefiind înzestrată cu valențe subiective.

Așadar, în cazul analizat în acest din urmă exemplu, judecătorul fondului nu are, de cele mai multe ori, nevoie să apeleze la resorturile extra-juridice ale normelor străine, întrucât misiunea sa este limitată la soluționarea litigiului pendinte. Desigur, într-un sistem de drept utopic, instanța s-ar concentra nu numai asupra regulii de drept străine, ci și asupra întregului din care aceasta face parte, respectiv a contextului istoric, economic și social al acelei ordini juridice. Avantajul integrării termenului de comparat în ordinea juridică din care provine se explică prin aceea că este imposibil de cunoscut „cu adevărat particula ce se examinează fără a cunoaște organismul din care ea face parte" ${ }^{97}$

În felul acesta, pe de-o parte, justițiabilul găsit vinovat este lămurit cu privire la motivul condamnării sale, iar, pe de altă parte, instanța judecătorească dobândește conștiința pronunțării unei soluții cât mai aproape de adevăr. În lipsa oricăror speranțe de atingere a acestui ideal, cel puțin în viitorul apropiat, ne limităm la recunoașterea meritelor juxtapunerii în înfăptuirea justiției sub aspectul dreptului internațional privat.

În al doilea rând, constatările comparatistul sunt, până la acest moment, strict obiective, ${ }^{98}$ constituind judecăți de fapt. În esență, comparatistul ia act de felul în care anumite instituții juridice sunt reglementate în diferite sisteme de drept, fapt ce contribuie la cunoașterea termenilor de comparat astfel cum aceștia sunt consacrați în legislațiile diferitelor țări. Întrucât comparatistul se limitează la expunerea reglementărilor naționale, este puțin probabil să se ivească, în cadrul aceluiași demers, păreri contradictorii între rezultatul cercetărilor sale și cele ale altor juriști. Spre exemplu, dacă mai mulți comparatiști studiază drepturile soțul supraviețuitor în mai multe sisteme de drept, concluzia la care aceștia vor ajunge este că soțul supraviețuitor fie beneficiază de un drept legal de abitație cu titlu temporar pe durata unui an, fie până la ieșirea din indiviziune, fie este privat de acest drept succesoral.

Din perspectiva noastră, considerăm că este dificil de atins rezultate diferite, în măsura în care termenii de comparat sunt selectați după aceleași criterii de timp și spațiu. Astfel, contradicțiile doctrinare cu privire la judecățile de fapt sunt extrem de reduse, poate chiar inexistente. Or, nu aceeași concluzie poate fi desprinsă în legătură cu compararea efectivă. În urma parcurgerii tuturor fazelor procesului metodologic, comparatistul, trasând asemănările și deosebirile între termenii de comparat, operează o judecată de valoare a cărei valoare nu poate fi decât subiectivă. Discursului comparativ i se imprimă o puternică amprentă subiectivă datorită investirii textelor normative cu valențe de oportunitate sau de eficiență. Din perspectiva observatorului, concluziile comparării pot părea neutre, însă rezultatul la care comparatistul ajunge în urma trasării relațiilor termenilor de comparat din punct de vedere al unității și diversității, nu pot fi decât impregnate cu subiectivism.

La o privire concluzivă, între juxtapunere și metoda comparativă nu există o relație de sinonimie. Juxtapunerea reprezintă, în esență, simpla alăturare a unor texte legislative care aparțin unor sisteme de drept diferite. ${ }^{99}$ Sunt foarte puține elemente în afara legii de care juristul să țină cont când utilizează juxtapunerea. ${ }^{100}$ 
Această operație implică doar mecanisme obiective care, așa cum am văzut, nu sunt lipsite de utilitate practică. Juxtapunerea conferă metodei comparative materia primă necesară pentru exprimarea unei păreri critice, în urma analizării asemănărilor și deosebirilor existente între termenii de comparat, prin prisma studierii și a părții invizibile a dreptului (examinarea mediului înconjurător, a ordinii sociale și a ansamblului de factori extra-juridici). Așadar, fiecare dintre cele două instrumente de cercetare trebuie delimitate cu precauție, întrucât servesc unor scopuri diferite, neputând exista o suprapunere între acestea.

\section{O definiție proprie a metodei comparative - demers adaptat cercetărilor juridice}

În considerarea informațiilor acumulate pentru redactarea prezentului studiu, dar și a concluziilor enunțate în secțiunile anterioare, propunem o nouă abordare asupra definiției metodei comparative care să exceleze prin ușurința formulării și prin utilitatea ei practică.

Conștient de controversele apărute între cercetători cu privire la numeroasele încercări de a concepe o definiție științifică a metodei comparative, în 1974, Leontin-Jean Constantinesco formulează o nouă definiție. ${ }^{101}$ Deși corectă din punct de vedere metodologic, definiția poate genera serioase incertitudini unui cercetător neinițiat în dreptul comparat.

Așadar, pentru a ușura procesul de înțelegere, dar și pentru a adapta metoda comparativă la realitățile practice, propunem o definiție proprie a acesteia. Astfel, prin metoda comparativă înțelegem o ustensilă epistemologică necesară în studiile de drept comparat prin care comparatistul se detașează de propriul sistem de drept, pentru a putea întreprinde o cercetarea interdisciplinară a mai multor ordini juridice străine (demers obiectiv), în vederea nuanțării asemănărilor și a diferențelor de substanță între termenii de comparat din ordini juridice diferite (demers subiectiv).

Considerăm că această definiție a metodei comparative este adecvată, pertinentă și accesibilă unui public mai larg.

Pentru început, o cercetare restrânsă la stadiul legislației și al codurilor din ordinile juridice studiate nu poate constitui un fundament pentru un studiul de drept comparat. Astfel, demersul comparativ trebuie să cuprindă pe lângă analiza legilor și a codurilor, cercetarea doctrinei, jurisprudenței, practicii în afaceri și a cutumei. Mai mult, cercetătorul este nevoit să apeleze la istoria, sociologia și literatura specifică ordinii juridice studiate.

În această fază, comparatistul recoltează informația, precum minerul colectează zăcăminte naturale, așadar toate acțiunile sale sunt obiective, fiind detașate de opinia personală a acestuia și se caracterizează prin rezistența la prejudecățile propriei culturi juridice.

Etapa obiectivă de detașare și cunoaștere nu oferă singură soluții de profunzime în domeniul dreptului comparat. Așadar, după ce comparatistul a cunoscut și a înțeles în detaliu termenii de comparat, acesta va stabili raporturile de asemănare și de deosebire între aceștia. Demersul apreciativ este ghidat de impactul perspectivei și al experienței comparatistului. Activitatea subiectivă pe care o desfășoară cercetătorul, în această fază, presupune interpretare, analiză și comparație, în vederea atingerii scopului urmărit de autor. Numai prin îmbinarea 
viziunii obiective cu cea subiectivă, un studiu de drept comparat poate contribui la o mai bună înțelegere a unor sisteme de drept, la clarificarea regulilor pe care un legiuitor dorește să le adopte, la cunoașterea obiectivelor sociale pe care termenii de comparat le deservesc în diferite ordini juridice, la codificarea la nivel european a legislațiilor etc.

Prin urmare, folosind rigorile enunțate în definiția propusă a metodei comparative, comparatistul este capabil să formuleze o concluzie de substanță asupra imaginii de ansamblu a ordinii juridice, atribuindu-i studiului de drept comparat un veritabil caracter trans-disciplinar, dar și un statut de lucrare științifică de referință în literatură.

\section{Concluzie}

În cuprinsul acestui studiu, am realizat o prezentare cronologică a evoluției metodei comparative, prin trimiteri la materiale bibliografice din spațiul european și cel angloamerican. Structura studiului a urmărit o sistematizare a demersului de utilizare a metodei comparative în studiile de drept comparat, urmărind ca finalitatea practică să constea în transpunerea noțiunilor teoretice în exemple concrete.

Totodată, am demonstrat faptul că, între juxtapunere și metoda comparativă nu există o relație de sinonimie. Juxtapunerea conferă metodei comparative materia primă necesară pentru exprimarea unei păreri critice, în urma analizării asemănărilor și deosebirilor existente între termenii de comparat.

La finalul discursului argumentativ, am formulat o nouă definiție a metodei comparative. Prin aceasta am urmărit să oferim cercetătorilor un punct de sprijin în delimitarea clară a conținutului demersului obiectiv și a celui subiectiv. Astfel, elaborarea un veritabil studiu de drept comparat este posibilă numai prin parcurgerea strictă a etapelor indicate.

Încheiem prin încurajarea cercetătorilor ca, în studii de drept comparat, în tezele de doctorat, în monografii sau articole, să utilizeze în mod riguros metoda comparativă.

\footnotetext{
* Student-doctorand la Universitatea „Babeș-Bolyai”, Facultatea de Drept din Cluj-Napoca, sub coordonarea prof. univ. dr. Mircea Dan BOB, LL.M. in Comparative Law la Louisiana State University, Louisiana, Statele Unite ale Americii, avocat în Baroul Cluj. Poate fi contactată la adresa de e-mail: alina.ciortea@law.ubbcluj.ro.

${ }^{1}$ Günter Frankenberg, Critical Comparisons: Rethinking Comparative Law, Harvard International Law Journal nr. 26/1986, p. 411-412.

${ }^{2}$ Günter Frankenberg, op.cit., p. 412.
} 
${ }^{3}$ Demersul obiectiv este intitulat, în literatura de specialitate americană necesară pentru a putea desluși cine suntem, încotro ne îndreptăm și ce gândim. Procedeul „decentralizează” lumea pe care o cunoaștem, injectând obiectivitatea cercetării. Astfel, acest demers este util pentru a ne putea detașa de cunoștințele bine sedimentate, de prejudecățile care ne înconjoară și de ignoranța de care dăm uneori dovadă. Günter Frankenberg, op.cit., p. 414.

${ }^{4}$ Doctrina americană accentuează importanța amprentei perspectivei și a experienței personale a observatorului, fie el turist sau comparatist, pentru a preveni confuzia noțiunilor acumulate. Günter Frankenberg, op.cit., p. 414. Pentru mai multe detalii cu privire la aserțiunea imposibilității existenței unei comparații obiective, a se vedea Günter Frankenberg, op.cit., p. 415 și urm.

${ }^{5}$ Pentru o prezentare amplă, a se vedea Leontin-Jean Constantinesco, Tratat de drept comparat, Vol. I Introducerea în dreptul comparat, ed. ALL Educațional, București, 1997, p. 195 și urm.

${ }^{6}$ Leontin-Jean Constantinesco, Tratat de drept comparat, Vol. II Metoda comparativă, ed. ALL Educațional, București, 1998, p. 7.

${ }^{7}$ Pentru detalii, a se vedea Leontin-Jean Constantinesco, op.cit. (1997), p. 185 și urm.

${ }^{8}$ Leontin-Jean Constantinesco, op.cit. (1998), p. 9.

${ }^{9}$ Este indubitabil că aceste aspecte conduc la atribuirea caracterului trans-disciplinar metodologiei comparative.

${ }^{10}$ Leontin-Jean Constantinesco, op.cit. (1998), p. 12.

${ }^{11}$ Pentru detalii, a se vedea infra, secțiunea III.

${ }^{12}$ S-a susținut că o atare abordare este specifică respectivei perioade. În secolul al XIX-lea a avut loc revoluția în matematică, fapt ce a condus la transpunerea unui important curent doctrinar și în drept. Béatrice Jaluzot, Méthodologie du droit comparé. Bilan et Prospective, Revue International de Droit Comparé nr. 1/2005, p.30.

${ }^{13}$ Discursul său a avut ca fundament cercetările autorilor Bernhöft și Cohn. Béatrice Jaluzot, op.cit., p.30.

14 Ibidem.

${ }^{15}$ Macro-compararea are ca scop studiul taxonomiei sistemelor juridice, iar micro-comparare urmărește compararea a două instituții juridice și soluțiile oferite de acestea unei probleme identice. Béatrice Jaluzot, p.46. Raportat la funcția fundamentală a metodei comparative, respectiv de a furniza noi cunoștințe, se poate afirma că micro-compararea pregătește calea macro-comparării, iar cea din urmă întemeiază știința dreptului comparat. Leontin-Jean Constantinesco, op.cit. (1998), p. 257.

${ }^{16}$ Béatrice Jaluzot, op.cit., p.32.

17 Denumirea a fost atribuită de Leontin-Jean Constantinesco. K. Zweigert și H. Kötz au intitulat-o „metoda legislativă”. Idem, p.31. În fond, ceea ce contează cu adevărat este mecanismul de funcționare al acestei metode și nu denumire efectivă pe care o poartă, întrucât fondul și nu forma definește, cel mai adesea, o entitate.

${ }^{18}$ Leontin-Jean Constantinesco, op.cit. (1998), p. 160 și urm.

19 Pentru detalii, a se vedea Olivier Moréteau, Codes as Straight-Jackets, Safeguards, and Alibis: The Experience of the French Civil Code, North Carolina Journal of International Law and Commercial Regulation nr. 20/1994-1995, p. 273 și urm.

${ }^{20}$ Leontin-Jean Constantinesco, op.cit. (1998), p. 180.

${ }^{21}$ Béatrice Jaluzot, op.cit., p.33.

${ }^{22}$ Idem, p.34.

${ }^{23}$ Ibidem.

${ }^{24}$ Leontin-Jean Constantinesco, op.cit. (1998), p. 123.

25 Ibidem. 
${ }^{26}$ Cunoașterea elementelor de comparat va fi analizată, în detaliu, în secțiunea dedicată juxtapunerii. A se vedea infra.

${ }^{27}$ Comparatistul trebuie să utilizeze surse originale, autentice și cu valoare științifică. Pentru aceasta, el trebuie să depășească bariera lingvistică, barieră care există și în situația în care cercetătorul cunoaște în profunzime limba în care lucrează. Este celebră dificultatea de a traduce un termen și de a-I transpune într-o ordine juridică străină lui. Spre exemplu, a se vedea infra discuția referitoarea la valențele termenului „Equity” în sistemul de Civil Law și Common Law.

${ }^{28}$ Leontin-Jean Constantinesco, op.cit. (1998), p. 134 și urm.

${ }^{29}$ Idem, p. 124.

${ }^{30}$ Spre exemplu, dacă elementul arhitectural aparține unui pasaj pietonal, după analizarea lui în detaliu, turistul se va îndepărta de particularitățile intrinseci ale acestuia pentru a pune în valoare poziția elementului raportat la întreg, rolul său în cadrul decorativ sau necesitatea acestuia raportat la structura de rezistență a podului. În măsura în care nu întreprinde aceste din urmă operațiuni, cum ar putea ști dacă elementul arhitectural studiat este fezabil pentru un pod rutier, de pildă? Cum ar putea stabili care sunt asemănările și deosebirile față de decorațiile unui pasaj pietonal din țara de origine a turistului?

${ }^{31}$ Leontin-Jean Constantinesco, op.cit. (1998), p. 124.

32 Idem, p. 121.

${ }^{33}$ Idem, p. 258.

34 Marie-Claire Ponthoreau, Le Droit Comparé en Question(s). Entre Pragmatisme et Outil épistémologique, Revue International de Droit Comparé nr. 1/2005, p. 13.

35 Idem, p. 13, 17.

${ }^{36}$ Procesul de descoperire implică ideea de „pre-cunoaștere”, prin care informațiile noi sunt alese în funcție de cele familiare comparatistului. Este greu de imaginat, poate imposibil, un inginer în postura de comparatist a două ordini juridice diferite. Neavând noțiunile de drept, din propriul sistem de juridic, cunoscute și înțelese, acesta nu poate întreprinde un demers științific comparativ. Precunoașterea este însoțită și un proces de reconstrucție care nu necesită automat uitarea cunoștințelor acumulate de comparatist, ci abilitatea acestuia de reconstrucție a cunoștințelor sale pentru a putea integra o altă manieră de a raționa în drept. Idem, p. 11-14.

${ }^{37}$ Günter Frankenberg, op.cit., p. 412.

${ }^{38}$ Leontin-Jean Constantinesco, op.cit. (1998), p. 124.

${ }^{39}$ A se vedea supra secțiunea I.

${ }^{40}$ Leontin-Jean Constantinesco, op.cit. (1998), p. 12.

${ }^{41}$ Idem, p. 52.

42 Ibidem.

43 Idem, p. 53.

${ }^{44}$ Marie-Claire Ponthoreau, op.cit., p. 13-14.

${ }^{45}$ Prin tertium comparationis se înțelege „existența unui drept obiectiv, superior, un fel de drept natural, de drept ideal". Leontin-Jean Constantinesco, op.cit. (1998), p. 24. Elementele supuse comparării nu sunt niște constante, ci sunt elemente variabile, cărora comparatistul trebuie să le stabilească punctele comune și raporturile existente între acestea, fără a exista o intenție de estimare, în absolut, valoarea obiectelor comparate. Idem, p. 10.

${ }^{46}$ Idem, p. 27. Nu insistăm asupra mai multor detalii cu privire la noțiunea de tertium comparationis, întrucât aceasta excedă obiectivul prezentului articol. 
47 Idem, p. 52.

48 În traducere, echitate.

49 Idem.

50 Este vorba despre King's Bench, Common Pleas și Exchequer. Toate acestea sunt considerate instanțele Regelui. William Geldart, Sir William Searle Holdsworth, Elements of English Law, ed. Oxford University Press, 1945, p. 34.

${ }^{51}$ Un ordin emis de către Rege prin care acesta din urmă chema o persoană, împotriva căreia a fost depusă o plângere, în fața King's Courts, adică în fața instanțelor Regelui. Idem, p. 35.

52 La origine, numărul writ-urilor nu era limitat, putând fi formulat un writ pentru orice circumstanță care apărea în practică. Ulterior însă, datorită frecvenței anumitor cazuri asemănătoare, acestea au fost grupate în anumite writ-uri, numărul acestora devenind astfel restrâns. Aladar Sebeni, Le "tort of negligence" en droit anglais, In Honorem Corneliu Bîrsan, ed. Hamangiu, București, 2013, p. 281.

${ }^{53}$ Remediul principal era posibilitatea reclamantului de a obține nulitatea relativă a contractului încheiat sub imperiul violenței. William Geldart, Sir William Searle Holdsworth, op.cit., p. 48.

${ }^{54}$ Această stare de fapt a făcut obiectul unui proces judecat de instanțele americane în anul 1979. Francois v. Francois, 599 F.2d 1286, United States of Appeals, Third Circuit, 1979.

55 Cititorul poate fi surprins, în acest context, de utilizarea termenului „inechitabil”. Aici, noțiunea de echitate, cu valențele sale, nu este folosită ca instituție juridică sau ca normă de drept, ci ca o judecată de valoare cu privire la efectele legii. Manuel Rodriguez Ramos, "Equity" in the Civil Law: A Comparative Essay, Tulane Law Review nr. 44/1969-1970, p. 721.

${ }^{56}$ Este cunoscut faptul că, acțiunea judiciară, în dreptul englez, nu este justificată de existența prealabilă a unui drept subiectiv, ci writ-ul în sine dădea naștere dreptului subiectiv, permițând persoanelor să ịși valorifice dreptul material în fața instanțelor de judecată. Leontin-Jean Constantinesco, Tratat de drept comparat, Vol. III Știința dreptului comparat, ed. ALL Educațional, București, 2001, p. 373.

57 George P. Fletcher, Steve Sheppard, American Law in a Global Context. The Basics, ed. Oxford University Press, New York, 2015, p. 63, 338 și urm.

58 Pârâtul dintr-un proces judecat în temeiul normelor de Common Law nu depunea jurământ. Desigur, existau mai multe diferențe între normele procedurale aplicabile de instanțele judecătorești care aplicau Common Law și cele conduse de Cancelar. Pentru mai multe detalii, a se vedea William Geldart, Sir William Searle Holdsworth, op.cit., p. 38-40.

59 Idem, p. 45.

${ }^{60}$ Idem, p. 57-60.

${ }^{61}$ Leontin-Jean Constantinesco, op.cit. (1998), p. 65-66.

62 În sensul că norma de drept emană de la puterea legislativă, aleasă democratic de către popor. Pe de altă parte, în sistemul de drept anglo-saxon precedentul judiciar, alături de legislație, constituie izvor direct de drept, deci judecătorul este creator de drept. Pentru detalii, a se vedea Edgar Bodenheimer, John Oakley, Jean Love, An Introduction to the Anglo-American Legal System: Readings and Cases, ed. Thomson West, Statele Unite, ed. a 4-a, p. 79 și urm.

${ }^{63}$ Leontin-Jean Constantinesco, op.cit. (2001), p. 374.

${ }^{64}$ În acest sens sunt dispozițiile art. 5 din Codul Civil francez (Art.5: "Il est défendu aux juges de prononcer par voie de disposition générale et réglementaire sur les causes qui leur sont soumises."). În sistemele de inspirație romano-germanică, jurisprudența este considerată izvor indirect de drept. Pentru detalii, a se vedea Olivier Moréteau, Codes as Straight-Jackets, Safeguards, and Alibis: The Experience of the French Civil Code, North Carolina Journal of International Law and Commercial Regulation nr. 20/1994- 
1995, p. 273 și urm. Aceeași concluzie poate fi susțină și în dreptul român unde, potrivit art. 5 Noul Cod de Procedură Civilă, îi este interzis judecătorului, prin hotărârile pe care le pronunță, să stabilească dispoziții general obligatorii.

${ }^{65}$ Articolul 11 din Proiectul Codului Civil expunea, în esență, faptul că atunci când judecătorul nu are la îndemână o normă juridică care să se aplice la situația factuală cu care se confruntă, el va judecata apelând la echitate. Astfel, echitatea este definită ca fiind resortul la dreptul natural și la uzanțe.

${ }^{66}$ Manuel Rodriguez Ramos, op.cit., p. 721.

67 Ibidem.

${ }^{68}$ Articolul 1194 din Codul civil francez, astfel cum a fost reglementat prin art. 2 din Ordonanța nr. 131 din 10 februarie 2016, are următorul conținut: "Les contrats obligent non seulement à ce qui y est exprimé, mais encore à toutes les suites que leur donnent l'équité, l'usage ou la loi."

69 J.-Michel Doyon, Droit, Loi et Équité, Revue Générale de Droit, vol. 26, nr. 2/1995, p.330.

70 Văzută ca și o creație emanând preponderent de la Parlament, asigurându-se astfel supremația poporului francez.

71 J.-Michel Doyon, op.cit., p.331.

72 P.-A. Fenet, Recueil complet des travaux préparatoires du Code civil, Titre préliminaire, De la publication, des effects et de l'application des lois en général, présentation au Corps législatif, éxpose de motifs par le conseiller d'état Portalis, 4 ventôse an XI, tome VI, p.359 și urm. apud J.-Michel Doyon, op.cit., p.331.

${ }^{73}$ J.-Michel Doyon, op.cit., p.332.

74 Desigur, există și în dreptul român dispoziții legale care fac trimitere directă la noțiunea de echitate, dintre care amintim: art. 630 alin. (1) Cod civil (Depășirea limitelor normale ale vecinătății), art.624 alin. (1) Cod civil (Starea de necesitate), art. 716 alin. (3) Cod civil (Lucrările și îmbunătățirile în materie de uzufruct), art. 1222 Cod civil (menținerea contractului în caz de existență a leziunii), art. 1271 alin. (3) lit. a) Cod civil (Adaptarea contractului în caz de impreviziune), art. 1272 Cod civil (Conținutul contractului). Însă, pentru a crește complexitatea studiului, am ales să nu tratăm aceste cazuri întrucât dezbaterea textelor legale din dreptul român ar fi similară cu cea efectuată în considerarea normelor din dreptul francez.

${ }^{75}$ Antecesorul ar fi avut vocație jure proprio, dacă acesta nu ar fi predecedat sau considerat nedemn față de de cuius.

${ }^{76}$ Instituția reprezentării nu este o inovație a Codului civil din 2011. Aceasta a fost cunoscută încă de la lustinian (Inst. III.1.6), când reprezentantul succeda în locul reprezentatului în virtutea dreptului său propriu. Mircea Dan Bob, Manual Elementar de Drept Privat Roman, ed. Universul Juridic, București, 2016, p. 322. Reprezentarea era consacrată și în vechiul nostru drept: Grava 273 din pravila lui Matei Basarab, cap. XXXVII, parag. 1 și 8 din Codul lui Andronache Donici, partea IV, Cap. III din Codul Caragea, art. 924 din Codul Calimach. Instituția și-a continua existența și în Codul civil 1864, în cuprinsul art. 664 și urm. În dreptul cutumiar francez, reprezentarea nu a fost, pentru multă vreme, recunoscută. Un prim pas către consacrarea legislativă a acesteia, a reprezentat-o validarea actelor numite „rappels à la succession" care produceau aceleași efecte ca reprezentarea, însă numai în situația în care defunctul avusese grijă să dispună în acest sens printr-un act mortis causa. M.G. Rarincescu, Curs de Drept Civil. Succesiuni - Donațiuni. Contractul Matrimonial, ed. Cursurilor Litografiate, București, 1943, p. 92-93. În prezent, Codul civil francez, la art. 751 și urm., reglementează instituția legală a reprezentării în materie succesorală. 
77 "Pari ratione et si nepos neptisque sit ex filio et ex nepote pronepos proneptisve, simul vocantur" (Inst. III.1.6). În traducere: „În adevăr, este echitabil ca nepoții și nepoatele să ia locul tatălui lor”.

${ }^{78}$ Matei B. Cantacuzino, Elementele Dreptului Civil, ed. Cartea Românească, București, 1921, p. 222; Dan Chirică, Tratat de Drept Civil. Succesiuni și liberalități, ed. C. H. Beck, București, 2014, p. 43.

${ }^{79}$ Fr. Deak, R. Popescu, Tratat de drept succesoral. Vol. I Moștenirea legală, ed. Universul Juridic, București, 2013, p. 148-149.

${ }^{80} \mathrm{Cu}$ mențiunea că, atât sistemul juridic francez, cât și cel român aparțin familiei romano-germanică, spre deosebire de Anglia al cărei sistem de drept este reprezentativ pentru sistemul anglo-saxon.

${ }^{81}$ Leontin-Jean Constantinesco, op.cit. (1998), p. 63.

${ }^{82}$ Articolul 565 din Codul civil francez are următorul conținut: "Le droit d'accession, quand il a pour objet deux choses mobilières appartenant à deux maîtres différents, est entièrement subordonné aux principes de l'équité naturelle. Les règles suivantes serviront d'exemple au juge pour se déterminer, dans les cas non prévus, suivant les circonstances particulières."

${ }^{83}$ George P. Fletcher, Steve Sheppard, op.cit., p. 347

${ }^{84} \mathrm{Ibidem}$.

${ }^{85}$ Sistem de care aparține atât dreptul român, cât și cel francez.

${ }^{86}$ Leontin-Jean Constantinesco, op.cit. (1998), p. 63.

${ }^{87}$ A se vedea observația lui François Gény referitor la articolul 565 din Codul Civil francez.

88 Idem, p. 61-62.

89 În situația în care comparatistul ajunge la concluzia comparabilității termenilor de comparat, acesta poate duce până la capăt demersul științific întreprins, iar utilitatea cercetării sale nu riscă să fie pusă la îndoială.

${ }^{90}$ Am ales să tratăm împreună echitatea din sistemul de drept românesc, cu équité din dreptul francez, întrucât, pe lângă faptul că ambele sisteme aparțin familiei romano-germanice, observăm că echivalență lingvistică este dublată de o echivalență juridică. A se vedea Manuel Guțan, Sisteme de drept comparate. Introducere în teoria generală a dreptului comparat, ed. Hamangiu, București, 2014, p. 208.

${ }^{91}$ Din punct de vedere filosofic, s-ar putea discuta despre comparabilitatea acestor noțiuni, însă o atare analiză excedă scopului prezentului studiu.

92 Leontin-Jean Constantinesco, op.cit. (1998), p. 49-51.

93 În sistemele de drept aparținând acelorași familii juridice (Spania, Franța, Italia, România etc.) există un număr nelimitat de situații în care echivalența juridică se întâlnește la nivelul termenilor de comparat. Spre exemplu, cauza exoneratoare de răspundere a forței majore din dreptul român este identică cu varianta franceză cunoscută sub numele de force majeur. De asemenea, între îmbogățirea fără justă cauza ca fapt juridic licit generator de obligații potrivit art. 1345 și urm. Cod civil poate fi trasat un paralelism juridic cu aceeași instituție din dreptul francez, anume l'enrichissement injustifié, prevăzută de art. 1303 și urm. Codul civil francez. Și, desigur, lista poate continua.

94 Utilizarea, în acest context a termenului „comparatist” nu este întocmai exactă, însă pentru a asigura fluența discursului, dar și pentru a evita unele confuzii ce ar putea fi create, înțelegem ca, de fiecare dată când folosim noțiunea de comparatist în secțiune dedicată juxtapunerii, să ne referim la cercetătorul care efectuează studii de drept străin.

${ }^{95}$ Leontin-Jean Constantinesco, op.cit. (1998), p. 49-51.

${ }^{96}$ Ibidem, p. 125.

${ }^{97}$ Leontin-Jean Constantinesco, op.cit. (1998), p. 213. 
98 Este discutabil, totuși, în ce măsură există într-adevăr o obiectivitatea strictă. Pentru început, comparatistul selectează contextul legal în care își va desfășura cercetarea, limitându-și domeniul și cadrul acțiunii. Selecția operează în funcție de domeniul de specialitate al autorului, de limba străină pe care o cunoaște, de disponibilitatea și accesibilitatea materialului bibliografic etc. Totodată, sistemele de referință pe care comparatistul le alege depind, din nou, de abordarea pe care dorește să o adopte acesta. Astfel, cercetătorul fie pornește demersul comparativ de la principiile generale, fie de la cazuri concrete și felul în care acestea au fost soluționate în diferite sisteme de drept. Günter Frankenberg, op.cit., p. 431.

${ }^{99}$ Termenul de juxtapunere provine din latinescul "juxta" care semnifică „alături” și din cuvântul franțuzesc „poser” care înseamnă „a pune”.

100 Günter Frankenberg, op.cit., p. 433.

${ }^{101}$ A se vedea supra. 